DOI: $10.12737 /$ article_5967ea62876972.45871734

УДК 630.502 .1

ЛАНДШАФТНО-ЭКОЛОГИЧЕСКАЯ ОЦЕНКА ТЕРРИТОРИИ БОЛЬНИЦЫ (НА ПРИМЕРЕ ГОРОДСКОЙ БОЛЬНИЦЫ Г. ВОРОНЕЖА)

кандидат сельскохозяйственных наук, доцент Н. П. Карташова ${ }^{1}$

кандидат сельскохозяйственных наук А. С. Селиванова ${ }^{1}$

1 - ФГБОУ ВО «Воронежский государственный лесотехнический университет имени Г.Ф. Морозова»,

г. Воронеж, Российская Федерация

Озелененные территории имеют огромное значение для населения городов и поселков. Они выполняют санитарно-гигиенические, эстетические, рекреационные функции, защищают от пыли, газов, шума, тем самым способствуют созданию наиболее благоприятных условий для жизнедеятельности населения. Одним из значимых объектов озеленения являются территории больниц, которые имеют ряд особенностей в озеленении и благоустройстве, так как служат дляотдыха и восстановления здоровья больных. Территории больниц необходимо изолировать от прилегающих улиц и площадей, должны быть предусмотрены автостоянки для сотрудников и посетителей, желательно, чтобы была выделена зона сада, где можно предусмотреть оборудования площадки для аэро-, гелиотерапии, лечебной физкультуры. В озеленении необходимо использовать виды растений и деревьев, которые выделяют фитонциды (эфирные масла, смолы и т. п.) игубительно действуют не только на сапрофитные, но и патогенные микроорганизмы. Например, фитонциды листьев березы, тополя и пихты убивают стафилококки, стрептококки, возбудителей туберкулеза. Хвоя и листья дуба выделяют фитонциды, которые убивают кишечную флору.Поэтому для озеленения территории больницы можно использовать различные декоративные деревья (березу, каштан, клен, липу и др.), кустарниковые (сирень, жасмин и др.) и вьющиеся (виноград, плющ, лианы и др.) растения. Исследование территории больницы г. Воронежа проводились при использовании методик оценки состояния насаждений, санитарно-гигиенической и эстетической оценок, определения классов устойчивости, стадий дигрессий, рекреационной нагрузки. Даны рекомендации по функциональному зонированию территории больницы, мероприятиям по благоустройству и озеленению, в результате которых повысится качество отдыха и условия восстановления здоровья больных. Обоснован выбор ассортимента растений, который применяется на территориях больниц, выполнен баланс территории, даны рекомендации по уходу и содержанию.

Ключевые слова: тип пространственной структуры, санитарно-гигиеническая и эстетическая оценки,благоустройство, озеленение, функциональное зонирование, планировочное решение.

\title{
LANDSCAPE AND ECOLOGICAL ASSESSMENT OF THE TERRITORY OF THE HOSPITAL (ON THE EXAMPLE OF CITY HOSPITAL OF VORONEZH)
}

$\mathrm{PhD}$ in Agriculture, Associate Professor N. P. Kartashova ${ }^{1}$ $\mathrm{PhD}$ in Agriculture A. S. Selivanova ${ }^{1}$

1 - Federal State Budget Education Institution of Higher Education «Voronezh State University of Forestry and Technologies named after G.F. Morozov», Voronezh, Russian Federation

\begin{abstract}
Green areas have great importance for the population of cities and towns. They perform sanitary and hygienic, aesthetic, recreational functions; protect from dust, gases, noise, and thereby contribute to creating the most favorable conditions for the life of the population. One of the important objects of gardening are areas of the hospitals, which have a number of features in gardening and landscaping as they have been used for rest and recovery of health of patients. Hospital grounds should be isolated from adjoining streets and areas parking spaces for employees and visitors shall be provided, it is advisable to select the area of the garden where it is possible to provide a hardware platform for aero- and heliotherapy, physical therapy. Species of plants and trees which emit phytoncides (essential oils, resins, etc.) and have detrimental effect not only on the saprophytic, but also pathogenic microorganisms must be used in landscaping. For example, the volatile leaves of birch, poplar and fir kill Staphylococcus, Streptococcus, pathogens of tuberculosis. Pine needles and oak leaves emit volatiles, which kill the intestinal flora. Therefore, you
\end{abstract}




\section{Ландшафтно-рекреационные насаждения}

can use various ornamental trees (birch, chestnut, maple, Linden, etc.), shrubs (lilac, Jasmine, etc.) and curly plants (grapes, ivy, vines, etc.) plants for landscaping of the hospital. Research of the hospital territory of the city of Voronezh was performed using methods to assess the state of the forests sanitary and hygienic and aesthetic evaluations, the class definitions of sustainability, the stages of degradation, recreational load. Recommendations on functional zoning of the territory of the hospital, and measures for the landscaping, which will increase the quality of rest and conditions of restoration of patients ' health are given. The choice of the range of plants that applies in the territories of hospitals is justified, the balance of the area is made, and recommendations for care and maintenance are given.

Keywords: type of spatial structures, sanitary and hygienic and aesthetic evaluation, beautification, greening, functional zoning, planning decision.

Система зеленых насаждений города - это взаимоувязанное, равномерное размещение городских насаждений, определяемое сложившейся системой дальнейшего развития, предусматривающее связь с загородными насаждениями. Зеленые территории представлены парками, скверами, бульварами, которые имеют огромное значение для населенных мест. Также огромную роль в системе озеленения играют объекты ограниченного пользования - территории школ, больниц, детских садов, промышленных предприятий, высших учебных заведений.

Насаждения при больницах и других лечебнопрофилактических учреждениях представляют собой озелененнуютерриторию для прогулок, отдыха и специальных процедур и играют значительную роль в озеленении всего населенного пункта. Ассортимент древесных растений для озеленения больниц рекомендуется дополнить видами, отличающимися способностью активно выделять фитонциды и отрицательнозаряженные ионы, но избегать пород с летучими волосистыми семенами, сильно пылящимися во время цветения [4].

Принципы озеленения больничных участков определяются общей схемой их планировки и целевым назначением насаждений. По внешнему периметру больницы создается плотная зеленая полоса из нескольких рядов деревьев и кустарников. Участки, на которых размещены хозяйственные постройки и подсобные сооружения, изолируют от остальной территории достаточно плотными линейными посадками. Для защиты прилегающих участков к дорогам от пыли и шума вдоль проездов высаживают ряды деревьев и кустарников. Согласно нормативным документам, между зонами и по периметру территории больницы предусмотрена полоса зеленых насаждений шириной не менее 15 м [6].
Объектом исследования послужила территория областной клинической больницы № 1, расположенная в городе Воронеже, показанная на рис. 1. Данная больница является многопрофильной, поэтому используется все разнообразие сильнотерапевтических факторов с учетом специфики и профиля входящих в состав больницы отделений.

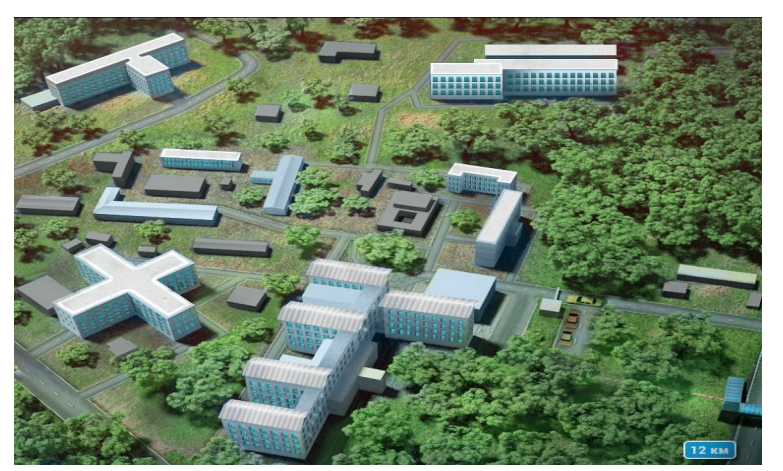

Рис. 1. Территория областной клинической больницы № 1

Территория больницы расположена в пределах городской черты и является внугригородским объектом ограниченного пользования, которая предназначена для нахождения медперсонала, служебного транспорта и автотранспорта посетителей, размещения хозяйственных построек, кратковременного пребывания посетителей больницы.По нормативным данным застройка земельного участка не должна превышать $15 \%$, озеленение - не менее $60 \%$. На хозяйственный двор, переходы, проезды остается почти 25 \% территории [5].

При исследовании территории больницы была выполнена ландшафтно-экологическая оценка, которая является неотьемлемой и самой важной частью предпроектного анализа состояния объекта. Именно по ее результатам и определяется весь комплекс необходимых мероприятий по улучшению территории. В ходе нее устанавливается тип пространственной структуры, 


\section{Ландшафтно-рекреационные насаждения}

класс устойчивости насаждений, стадия дигрессии, определяется эстетическая и санитарно-гигиеническая оценки, рекреационная емкость территории.

Территория ВОКБ № 1 по соотношению различных элементов ландшафта относится к полуоткрытому типу пространственной структуры. Имеются участки срединным,равномерным и групповым размещением деревьев сомкнутостью 0,3-0,5.

По шкале санитарно-гигиенической оценки насаждений объектотносится к первому классу, так как сумма коэффициентов составила 7. На территории исследования преобладают хвойные породы, обладающие высокой фитонцидной и воздухоочищающей способностью. Кроме того наблюдается хорошая вентиляция воздуха, отсутствие шума, паразитов, густых зарослей. Имеют место ароматические запахи, лесные звуки, сочные краски.

Оценка эстетических свойств ландшафта отражает красочность и гармоничность сочетания всех компонентов растительности и осуществляется путем визуального обследования. По шкале эстетической оценки территория больницы достигла 31 балла из 50 максимально возможных. Деревья и кустарники различного породного состава образуют ландшафтные группы, аллеи, живые изгороди, рядовые посадки, имеются живописные солитеры. Все это в совокупности создает красочность и выразительность пейзажа. Участок в целом имеет равнинный рельеф, хорошую проходимость, не захламлен. Насыщенность и уникальность объекта по наличию видовых точек незначительна, отсутствуют водные поверхности. Все это в совокупности и дает такую оценку, которую можно повысить путем проведения мероприятий по благоустройству и озеленению.

На территории больницы были определены категории состояния древесно-кустарниковой растительности (табл. 1).

Таким образом, 60 деревьев имеют хорошее состояние, без признаков ослабления; 353 дерева - удовлетворительное состояние, 35 \% которых ослабленные и $65 \%$ - сильно ослабленные. Однако большинство деревьев и кустарников нуждаются в омолаживающей и формирующей обрезке, внесении комплексных удобрений.

Согласно проведенной натурной оценки территории больницы № 1, участки с насаждениями сомкнутостью 0,5 достигли второй стадии дигрессии. Были выявлены незначительные изменения - ухудшение

Таблица 1

Перечетная ведомость древесно-кустарниковой растительности

\begin{tabular}{|c|c|c|c|c|c|c|}
\hline № & Наименование растений & Кол-во & Высотам & $\begin{array}{c}\text { Диаметр } \\
\text { см }\end{array}$ & $\begin{array}{l}\text { Категория } \\
\text { состояния }\end{array}$ & $\begin{array}{c}\text { Примечание, рекомендуе- } \\
\text { мые мероприятия }\end{array}$ \\
\hline \multicolumn{7}{|c|}{ Деревья } \\
\hline 1 & Сосна обыкновенная & 194 & $15-20$ & $20-30$ & 2 & обрезка \\
\hline 2 & Береза повислая & 98 & 25 & 22 & 2 & обрезка \\
\hline 3 & Ель обыкновенная & 60 & $20-25$ & $20-24$ & 2 & обрезка \\
\hline 4 & Ель колючая & 10 & 20 & 20 & 1 & обрезка \\
\hline 5 & Ива плакучая & 6 & 18 & 26 & 1 & обрезка \\
\hline 6 & Рябина обыкновенная & 8 & $15-20$ & 16 & 1 & обрезка \\
\hline 7 & Вяз мелколистный & 9 & $25-30$ & 30 & 2 & обрезка \\
\hline 8 & Клен остролистный & 12 & $10-15$ & 20 & 1 & санитарная обрезка \\
\hline 9 & Клен татарский & 9 & $10-15$ & 20 & 1 & обрезка \\
\hline 10 & Тополь пирамидальный & 2 & $25-30$ & 26 & 2 & санитарная обрезка \\
\hline 11 & Туя западная & 5 & $2-3$ & 5 & 1 & \\
\hline \multicolumn{7}{|c|}{ Кустарники } \\
\hline 12 & Можжевельник казацкий & 4 & $1-1,5 \mathrm{M}$ & 5 & 1 & обрезка \\
\hline 13 & Пузыреплодник калинолистный & живая изгородь & 0,8 & & 1 & омолаживающая обрезка \\
\hline \multirow[t]{2}{*}{14} & Сирень обыкновенная & 4 & $3-5$ & $10-15$ & 1 & омолаживающая обрезка \\
\hline & Итого & 421 & & & & \\
\hline
\end{tabular}

Примечание: 1 - без признаков ослабления; 2, 3 - ослабленные и сильно ослабленные; 4, 5 - усыхающие и сухостой: 6 - сухостой прошлых лет. 


\section{Ландшафтно-рекреационные насаждения}

роста и развития деревьев и кустарников, единичные их механические повреждения, почва и подстилка слегка уплотнены (до 5 \%). На остальной территории существенных недостатков в росте и развитии древесно-кустарниковой растительности, а также в изменении подстилки не выявлено, так как здесь проложена дорожно-тропиночная сеть с твердым покрытием, соединяющая корпуса больницы, что снижает уровень бездорожней формы рекреации.

Преобладающей породой является сосна обыкновенная, следовательно, объект относятся ко второму классу устойчивости.

Таким образом, определив стадию дигрессии и класс устойчивости, можно найти рекреационную нагрузку, воздействующую на данную территорию [2, 3]. Фактическая рекреационнаягрузка составляет 3,0 чел.дн./га, которая колеблется в пределах 2,0-4,0 чел.дн./га. Предельно-допустимая нагрузка составляет 8,0 чел.-дн/га, которая колеблется в пределах 4,0-12,0 чел.-дн./га. На территории больницы, площадь которой 5,1 га, фактическая рекреационная нагрузка составит 20,4 чел.-дн./га, предельно-допустимая - 61,2 чел.дн./га. Следовательно, фактическая нагрузка на объекте меньше предельно-допустимой, что свидетельствует о том, что объект обладает значительным рекреационным потенциалом.

Таким образом, сравнение предельно допустимых и фактических нагрузок является важным инструментом в регулировании численности, которое должно осуществляться, главным образом, за счет размещения элементов благоустройства на основе функционального зонирования территории.

Все данные проведенного предпроектного анализа позволяют выполнить функциональное зонирование территории.

На территории больничного комплекса функциональное зонирование призвано обеспечить надлежащий гигиенический и противоэпидемический режим, а также лечебно-охранительный комфорт пациентов и врачей.

В результате, на территории больницы выделены зона лечебного корпуса, хозяйственная и садовопарковая зоны. Хозяйственная зона смещена к границам территории. На ней размещаются автостоянка, проезд для транспорта, площадка для мусоросборников. К больничному корпусу № 1 прилегает садово- парковая территория для прогулок и тихого отдыха пациентов. Зона лечебного корпуса включает здания и прилегающую к ним территорию.

В выделенных функциональных зонах рекомендуется провести мероприятия по озеленению и благоустройству.

Ассортимент растений, проектируемых на территории больницы, отбираем с учетом наибольшей их устойчивости к данным климатическим условиям. При составлении композиций руководствовались экологобиологическими и морфологическими принципами подбора ассортимента. На территории объекта уже существуют посадки в виде массива и куртин. Однако необходимо введение дополнительных «зеленых» единиц, особенно в виде клумб и цветников $[7,8]$. Кроме того следует помнить, что при зеленом оформлении центрального участка больницы надо избегать введения в посадки в большом количестве пород с пирамидальными и плакучими формами крон, так как они действуют угнетающе на некоторых больных [1]. Рекомендуется использовать деревья и кустарники со «спокойными» яйцевидными, овальными и плакучими формами крон. Кроме того необходимо учитывать окраску растений. Если окраска растений приближается к средневолновым частям спектра со светлотой 50-70 \% и насыщенностью около $40 \%$, то такие растения оказывают неблагоприятное воздействие на человека. Для создания наиболее благоприятных условий необходимо рекомендовать устройство цветников, которые будут радовать глаз больных и посетителей. Весь рекомендуемый ассортимент растений представлен в табл. 3.

Таким образом, площадь озеленения под ландшафтными группами составит 100 м², в существующие куртины подсаживаем различные породы деревьев и кустарников, площадь озеленения которых составит $170 \mathrm{M}^{2}$, под цветники $-3430 \mathrm{~m}^{2}$.

В зоне лечебного корпуса рекомендуется создание подзоны кратковременного отдыха $[9,10]$. Данная территория будет оформлена в виде прямоугольной площадки, в центре которой установлен фонтан, а по периметру участка расположенымалые архитектурные формы - скамьи для отдыха в количестве 11 штук и 22 урны для мусора.

При каждом из лечебных корпусов создаем небольшой сад, огражденный растительностью от остальной территории, с площадками для проведения 
Таблица3

Посадочная ведомость

\begin{tabular}{|c|c|c|c|c|c|c|}
\hline \multirow{2}{*}{ № } & \multirow{2}{*}{ Ассортимент пород } & \multirow{2}{*}{$\begin{array}{c}\text { Площадь компонента } \\
\text { озеленения, } \text { м² }^{2}\end{array}$} & \multicolumn{3}{|c|}{ Количество растений, шт. } & \multirow{2}{*}{ Вид посадок } \\
\hline & & & деревья & кустарники & цветочные растения & \\
\hline 1 & Катальпа бигнониевидная & 84,0 & 21 & & & группа \\
\hline 2 & Береза повислая'Crispa' & 18,0 & 9 & & & куртина \\
\hline 3 & Слива растопыренная & 16,0 & 4 & & & группа, солитер \\
\hline 4 & Сумах оленерогий & 10,0 & 2 & & & куртина \\
\hline 5 & Лох узколистный & 20,0 & 4 & & & куртина \\
\hline 6 & Яблоня Недзвецкого & 28,0 & 7 & & & куртина \\
\hline 7 & Ель колючая 'Glauca' & 20,0 & 4 & & & куртина \\
\hline 8 & Ель обыкновенная 'Virgata' & 8,0 & 2 & & & группа \\
\hline 9 & $\begin{array}{l}\text { Можжевельник обыкновен- } \\
\text { ный 'Hibernica' }\end{array}$ & 18,0 & 6 & & & куртина \\
\hline 10 & Сирень обыкновенная & 13,0 & & 13 & & куртина группа \\
\hline 11 & Магонияпадуболистная & 295,0 & & 590 & & живая изгородь \\
\hline 12 & Сосна горная & 28,0 & & 14 & & группа, куртина \\
\hline 13 & Можжевельник средний & 35,0 & & 14 & & группа \\
\hline 14 & Форзиция промежуточная & 110,0 & & 220 & & живая изгородь \\
\hline 15 & Чубушник венечный & 20,0 & & 20 & & куртина \\
\hline 16 & Рудбекия & 250,0 & & & 830 & клумба \\
\hline 17 & Роза чайно-гибридная & 690,0 & & & 2300 & клумба, рабатка \\
\hline 18 & Котовник Фассена & 50,0 & & & 100 & клумба \\
\hline 19 & Вероника колосковая 'Erica' & 100,0 & & & 200 & клумба \\
\hline & ИТОГО & 1813,0 & 59 & 871 & 3430 & \\
\hline
\end{tabular}

специальных лечебных процедур и дорожками для прогулок больных и оснащаем эти территории беседками.

При формировании композиций из зеленых насаждений на территориях при лечебных корпусах подбирали разнообразные по форме и цвету растения, в том числе значительное количество вечнозеленых, а также многолетних цветочных растений и декоративно цветущих кустарников.

Мероприятия по озеленению и благоустройству изменят баланс территории объекта, который показывает соотношение планировочных элементов и пространственной структуры объекта, служит для определения площади дорог, водоемов, площадок, сооружений и насаждений [5] (табл. 4).

Баланс территории БУЗ ВО «Воронежской областной клинической больницы № 1»

\begin{tabular}{|c|c|c|c|c|c|}
\hline \multirow{3}{*}{$\begin{array}{l}\text { № } \\
\text { ா/ா }\end{array}$} & \multirow{3}{*}{ Наименование элементов } & \multicolumn{4}{|c|}{ Занимаемая площадь } \\
\hline & & \multicolumn{2}{|c|}{ до проектирования } & \multicolumn{2}{|c|}{ после проектирования } \\
\hline & & $\mathrm{M}^{2}$ & $\%$ & $\mathrm{M}^{2}$ & $\%$ \\
\hline \multirow{5}{*}{1} & $\begin{array}{l}\text { Насаждения: } \\
\text { Деревья }\end{array}$ & & & & \\
\hline & - одиночные & 86,0 & 0,17 & 94,0 & 0,18 \\
\hline & - куртина & 7084,0 & 13,89 & 7198,0 & 14,11 \\
\hline & - рядовая посадка & 352,0 & 0,69 & 352,0 & 0,69 \\
\hline & - группа & 128,0 & 0,25 & 232,0 & 0,45 \\
\hline \multirow[t]{4}{*}{2} & Кустарники & & & & \\
\hline & - одиночно & 472,0 & 0,93 & 472,0 & 0,93 \\
\hline & - группы & 20,0 & 0,04 & 82,0 & 0,16 \\
\hline & - живая изгородь & 306,0 & 0,6 & 405,0 & 0,79 \\
\hline 3 & Цветники & - & - & 1090,0 & 2,14 \\
\hline 4 & Газон & 27415,0 & 53,75 & 22836,4 & 44,78 \\
\hline 5 & Здания и сооружения & 11930,0 & 23,39 & 11930,0 & 23,39 \\
\hline 6 & Дороги и площадки & 3154,0 & 6,18 & 5914,0 & 11,6 \\
\hline 7 & МАФ & 53,0 & 0,11 & 379,6 & 0,75 \\
\hline \multirow[t]{2}{*}{8} & Водные сооружения & - & - & 15,0 & 0,03 \\
\hline & Итого & 51000,0 & 100 & 51000,0 & 100 \\
\hline
\end{tabular}




\section{Ландшафтно-рекреационные насаждения}

Таким образом, незначительноувеличится площадь под деревьями и кустарниками - на 1,2 \%, под дорогами - на 5,4 \%, появятся цветники, пло-

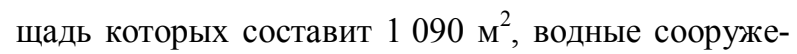

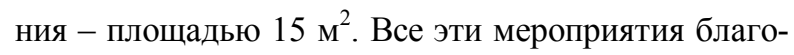
приятно скажутся на пребывании больных, медперсонале, а также посетителях.

Итак, на территории больницы появятся ор- ганизованные места для отдыха пациентов и персонала больницы, что ведет за собой увеличение площади дорожно-тропиночной сети и введение дополнительных зеленых насаждений в виде ландшафтных групп, живой изгороди, цветников, которые призваны повысить красочность ландшафта путем ярких цветовых акцентов и необычных форм.

\section{Библиографический список}

1. Боговая, И. О. Озеленение населенных мест [Текст] : учеб. пособие / И. О. Боговая, В С. Теодоронский. - Изд. 2-е, стер. - СПб. ; М. ; Краснодар : Лань, 2012. - 240 с.

2. Карташова, Н. П. О нормативах рекреационных нагрузок [Текст]: / Н. П. Карташова // Лес. Наука. Молодежь ВГЛТА 2003 : сб. материалов по итогам научно-исследовательской работы молодых ученых за 2003 год, посвященный 90-летию со дня рождения профессора П.Б. Раскатова ; под ред. акад. РАЕН, проф. Л. Т. Свиридова. - Воронеж, 2003. - С. 67-71.

3. Карташова, Н. П. Рекреационная емкость пляжных территорий и их благоустройство (на примере береговой линии реки Воронеж) [Текст] / Н. П. Карташова, А. С. Селиванова // Известия Санкт-Петербургской лесотехнической академии. - 2016. - Вып. 217. - С. 638-642.

4. Потаев, Г. А. Архитектурно-ландшафтный дизайн: теория и практика [Текст] : учеб. пособие / Г. А. Потаев. - М. : ФОРУМ ; ИНФРА-М, 2013. - 320 с.

5. Теодоронский, В. С. Объекты ландшафтной архитектуры [Текст] : учеб.пособие / В. С. Теодоронский, И. О. Боговая. - М., 2003. - 300 с.

6. Теодоронский, В. С. Озеленение населенных мест. Градостроительные основы [Текст] : учеб. / В. С. Теодоронский, Г. П. Жеребцова. - М. : Академия, 2010. - 256 с.

7. Bunio, L. V. Specific features of morphogenesis of sedge (Carexhirta L.) on oil-contaminated soil [Text] / L. V. Bunio, O. M. Tsvilynjuk // Contemporary Problems of Ecology. - 2015. - Vol. 8. - № 5. - P. 660-667.

8. Talovskaya (Kolegova), E. B. Thymus baicalensis (Lamiaceae) morphological transformation under different environmental conditions[Text] / E. B. Talovskaya (Kolegova) // Contemporary Problems of Ecology. - 2015. - Vol. 8. - № 5. - P. 607-613.

9. Turner, T. Open space planning in London [Text] / T. Turner // Strategic Planning Advice for London, October, 1988. - London, 1993. - P. 366-386.

10. Jaakson, R. Recreation zoning and lake planning [Text] / R. Jaakson // Town PlannRew. - 1972. - 43, № 1. - P. 41-55.

\section{References}

1. Bogovaya I. O. Ozelenenie naselennykh mest [Gardening of the inhabited places]. Prod. the 2nd, has erased. Saint Petersburg; Moscow; Krasnodar, 2012, 240 p. (In Russian).

2. Kartashova N.P. O normativakh rekreatsionnykh nagruzok [About standards of recreational loadings] Les. Nauka. Molodezh' VGLTA 2003: Sbornik materialov po itogam nauchno-issledovatel'skoj raboty molodyh uchenyh za 2003 god, posvjashhennyj 90-letiju so dnja rozhdenija professora P.B. Raskatova [Wood. Science. Youth of VGLTA 2003: The collection of materials following the results of research work of young scientists for 2003 devoted to the 90 anniversary since the birth of professor P. B. Raskatov]. Voronezh, 2003, pp. 67-71. (In Russian).

3. Kartashova N.P. Selivanova A.S. Rekreatsionnaya emkost' plyazhnykh territoriyi ikh blagoustroystvo (na primere beregovoy liniireki Voronezh) [Recreational capacity of beach territories and their improvement (on the example of the coastline of the river Voronezh)] Izvestiya Sankt-Peterburgskoj lesotehnicheskoj akademii [Izvestiya Sankt - the 
St. Petersburg timber college] Saint Petersburg, 2016, pp. 638-642. (In Russian).

4. Potaev G.A. Arkhitekturno-landshaftnyy dizayn: teoriya I praktika [Architectural landscaping: theory and practice]. Moscow, 2013, 320 p. (In Russian).

5. Teodoronskiy V.S. Bogovaya I. O. Ob"ekty landshaftnoy arkhitektury [Objects of landscape architecture]. Moscow, 2003, 300p. (In Russian).

6. Teodoronskiy V.S., Zherebtsova G.P. Ozelenenie naselennykh mest. Gradostroitel'nye osnovy [Gardening of the inhabited places. Town-planning bases]. Moscow, 2010, 256 p. (In Russian).

7. Bunio L. V., Tsvilynjuk O. M. Specific features of morphogenesis of sedge (Carexhirta L.) on oilcontaminated soil. Contemporary Problems of Ecology, 2015, Vol. 8, no 5, pp. 660-667.

8. Talovskaya (Kolegova) E. B. Thymus baicalensis (Lamiaceae) morphological transformation under different environmental conditions. Contemporary Problems of Ecology, 2015, Vol. 8, no. 5. pp. 607-613.

9. Turner T. Open space planning in London. Strategic Planning Advice for London, October, 1988. London, 1993, pp. 366-386

10. Jaakson R. Recreatio4n zoning and lake planning. Town PlannRew, 1972, 43, no. 1. pp. 41-55.

\section{Сведения об авторах}

Картамова Нелли Павловна - доцент кафедры ландшафтной архитектуры и почвоведения ФГБОУ ВО «Воронежский государственный лесотехнический университет имени Г.Ф. Морозова», кандидат сельскохозяйственных наук, доцент, г. Воронеж, Российская Федерация; e-mail: Kartashova_73@mail.ru.

Селиванова Ангелина Сергеевна - доцент кафедры ландшафтной архитектуры и почвоведения ФГБОУ ВО «Воронежский государственный лесотехнический университет имени Г.Ф. Морозова», кандидат сельскохозяйственных наук, г. Воронеж, Российская Федерация; e-mail: hatulina@mail.ru.

\section{Information about authors}

Kartashova Nelly Pavlovna - Associate Professor of Landscape Architecture and Soil Science department, Federal State Budget Education Institution of Higher Education «Voronezh State University of Forestry and Technologies named after G.F. Morozov», PhD in Agriculture, Associate Professor, Voronezh, Russian Federation; e-mail: Kartashova_73@mail.ru.

Selivanova Angelina Sergeevna - Associate Professor of Landscape Architecture and Soil Science department, Federal State Budget Education Institution of Higher Education «Voronezh State University of Forestry and Technologies named after G.F. Morozov», PhD in Agriculture, Voronezh, Russian Federation; e-mail: hatulina@mail.ru. 